\title{
THEORETICAL AND PRACTICAL ASPECTS REGARDING FORMING REPRESENTATIVE UNIVERSITY BASKETBALL TEAMS
}

Ionela Cristina NAE ${ }^{1}$

\begin{abstract}
Following my experience acquired in over 15 years working as a coordinating teacher of female and male representative basketball teams at the Bucharest University of Economic Studies, I considered usefull a scientific article, which should contain information about how to start university basketball teams.

The training activity carried out by the physical education teacher with the students during sport education class has to be oriented towards forming a team that can participate in the games marked in the competition calendar of a university year.

A basic requirement at this level is selection and finding the students with the proper skills needed for basketball.
\end{abstract}

Keywords: university basketball, selection, coach.

JEL classification:

DOI: $10.24818 / \mathrm{mrt} .20 .11 .02 .02$

\section{Introduction}

"The organization and content of extracurricular lessons has to assure the presence of technical-tactical basketball practices, in order to subsequently identify the most talented elements to form competitive university teams, but also to guide students towards performance sport.” (Popescu, 2010)

Most of Romania's universities have representatives in basketball, volleyball, handball, football and other sports. The choice of sports depends on the material resources, skills and desire of the students for a certain sport, the availability and specialization of the teacher, the university financial possibilities and not lastly, the university's tradition.

At the start of the university year, during the physical activity classes, students are asked about their health condition, past sport activity, etc. and those who have sport experience, at least in the high school representatives events are guided towards the suitable sport teams.

${ }^{1}$ Ionela Cristina Nae, The Bucharest University Economic Studies, cristinuta_criss@yahoo.com 
Another method of discovering talents is the systematic observation of students during sport classes and the skillful students are also guided to the proper team.

Students with the skillset for a specific sport and the willing to improve themselves during sports training classes, are selected in university representative teams aiming to participate in university competitions, according to the competition calendar.

The practice at this level is an activity through which talented students can continue their preparation for basketball.

\section{Steps in the selection process}

The first step is the aforementioned preliminary round, in which students are advised to the proper sport [section]. It lasts for approximately 1-2 weeks.

In the second phase, only the students who fulfill the following requirements are selected: adequate skills and physical prowess for a specific sport, a stable health condition and the availability to train for and participate in competitions. This stage extends to 1-2 weeks.

The third stage progresses over 2-6 weeks. The selection process is combined with the preparatory one. During this event, students undergo various tests, sometimes they are assessed through questionnaires. Also, throughout this phase, students are systematically observed in the course of training sessions and matches.

The fourth step is the relatively stable selection, in which one forms the team and identifies the best 5 players. We feel the need to mention that at this stage, selection is still open.

In order to form the representative university team, the coach has to:

- master the characteristics and structure of basketball at national and international level;

- $\quad$ have an individual conception about the game and adequate training;

- fully know each and every player, regarding level of preparation, performance and availability;

- evaluate the players' efficiency on their positions and the way in which they can evolve on other positions;

- the group's continuous dynamic - changing players from the lineup with other members, when it is necessary, so as to achieve the best results;

- $\quad$ study and evaluate the efficiency of the game plan during the previous University Championship in order to observe the proportionality between the players' performance and the tactical game plan.

The team's basic structure is a component of the game plan in which the position is mentioned and occupied by each player in the team (for example: four forwards, four wingers, four point guards). 
Chosen by the coach, the team's functional structure is the optimal representation and the most efficient. In other words, this formation raises the efficiency of inter-player collaboration to enhance the team's game in the field.

While forming the team, one might think of the total number of players. This figure is given by the game's regulations and may differ from one sport to other. The team is formed from the number of lineup players and reserves.

All positions from the team's basic structure are filled in by the lineup members, then in order of value, the reserves' positions are obtained by the other members. Thus one forms a hierarchy of players based on positions. The reserves can replace the lineup members anytime because one has to take into account the level of fitness of each player.

\section{Preparing the teams}

The organization, performance and content of training sessions has to develop a technical-tactical skillset for playing basketball at a high level.

This training process will be conducted while taking into consideration certain objectives, therefore, one has to organize and plan the activity progressively. To do so, one must follow each systematic milestones according to the preparation level of the selected students.

The instruction process during the physical activities classes is carried out under the form of training sessions. These coaching classes' purpose is to prepare the team to take part in university competitions.

For the university representative team, most students are selected because they already have experience based on their previous activity at sport clubs or high school representative teams. Despite this, there are also exceptions when there are inexperienced students part of the team. They were selected because of their special qualities or because of the reduced number of students that form the team, cases in which one must impose a vaster technical-tactical training schedule.

\section{The physical education teacher - the representative basketball team' coach \\ "The coach is a teacher, with high-level qualification, who participates} directly at the evolution of the basketball activity, and especially for developing the sport activity in general" (Predescu\&Ghitescu,2001)

The physical education teacher carries out the preparation activity with the students during sport classes. This work should be directed towards forming a team which can participate in the university-level year-long competition calendar.

"The work of forming a team has to and must remain one of the fundamental problems of the physical education teacher"(Predescu \& Moanta, 2001) in a school, high school or university. This work should be at the same level as the teaching activity with the students during the physical education class. Besides the obligations and skillset that the coach has as a teacher of physical education class, one has to: 
- organize, coordinate and lead the preparation;

- prepare plans for training sessions;

- be interested in this activity, dedicate oneself to the team;

- be preoccupied with one's professional development;

- prove communication skills inside the group;

- be a proper behavioral role model for your students;

- act according to the ethical code of work and society

- have psychological-pedagogical skills;

- be calm, understanding, have adaptability, authority, inspire confidence.

\section{The coach's obligations regarding competitive activity}

The competition - through the official game - is the teacher's essential moment because it offers the possibility of evaluating the preparation.

Alongside organizing, coordinating and leading the training sessions, the representative teams' coach also has obligations regarding competition activity, as well as administrative tasks:

- writing the chart with students that are part of the team. It should contain the university's header, the student's family name and first name, group, faculty, form of education and medical approval form;

- preparing the competition reimbursement forms for the arbitration panel and possible team's trips;

- $\quad$ announcing the competition's hour, date, place, equipment;

- establish the tactics for official and training games;

- present the chart with the team's lineup to the officials before the start of the game;

- supervise and coordinate warm-up before the game;

- changes players during the game when it is necessary and the game permits it;

- $\quad$ asks for a time out;

- thanks the referees for the performance and the other team's teacher after the game;

- fills in the administrative forms at the referee's table after the end of the game and picks up: the arbitration panel card, payroll and the list of members participating in the game.

The games held during university competitions are a checking point for the training the coach did with the students.

Analyzing the game in the first training session after the game is a component of the instructional and educational process, that's the reason why the teacher needs to keep a track of the students' efficiency during all the team's games. 


\section{The concept of the game}

In order to establish one's own concept of the game, the coordinating teacher of a university representative basketball team has to do the following activities:

- developing the instruction activity while considering one's thoughts about training and the game;

- drafting the planning documents using the templates done by the Romanian Basketball Federation;

- establishing the offensive system to use in competitions;

- creating training sessions as attractive as possible in order to stimulate the students' active participation;

- checking, consolidating and perfecting technical procedures;

- teaching the players to control the game's rhythm and tempo according to the opponent;

- teaching, consolidating and perfecting attack systems;

- $\quad$ harnessing the potential of each player according to efficiency;

- placing the players on positions corresponding to the system chosen for the game;

- $\quad$ establishing the structure of the team on positions;

- teaching defense systems;

- convincing players of the necessity of everyone participating in the team effort.

\section{Conclusions}

The primary demand of sport performance activity at university level is the selection meaning finding students with the right skillset, who have played basketball at junior level or in high school representative teams.

The concept regarding the selection and the preparation of the students in basketball is not a momentary act, but a process which is chronologically unfolding, in which the training stages are adapted as they evolve during training sessions. At the beginning, the selection shows the availability of those investigated, materialized through a sufficient content of skills and motor abilities needed in basketball, health condition, general motor behavior and not lastly, the powerful motivation for practicing this sport. It should be mentioned that generally, students practice basketball as a hobby, in their spare time, without having any financial profit.

The physical education teacher coaching activity with the students during the sport session needs to be guided towards forming a team which can participate in the competitions listed in the university competition calendar.

The results obtained in official games represent the method of of evaluating the training efficiency and selection activity led by the coach during a certain period of time. 


\section{REFERENCES}

1. Berceanu, D.; Moanţă, Alina, 2007. Concepţia de joc şi de pregătire pe nivele formative, Bucureşti, ANS, FR Baschet, Editura Printech

2. Ghiţescu, G., 2004.Baschet, fundamente teoretice şi metodice, Bucureşti, Editura ANEFS

3. Popescu, FlorentinA (2010), Baschet-Curs de bază, Editura Fundaţiei „România de mâine”, Bucureşti, p. 256

4. Predescu, Teodora, Ghiţescu G.,2001.Baschet, pregătirea echipelor de performanţă, Bucureşti, Editura Semne, p. 293

5. Predescu, Teodora, Ghitescu, G. (2001), Baschet - Pregătirea echipelor de performanță, Editura Semne, p. 293 